IZA DP No. 6604

The Formal Sector Wage Premium and Firm Size for Self-employed Workers

Olivier Bargain

Eliane El Badaoui

Prudence Kwenda
Eric Strobl

Frank Walsh

May 2012 


\title{
The Formal Sector Wage Premium and Firm Size for Self-employed Workers
}

\author{
Olivier Bargain \\ Aix-Marseille School of Economics and IZA \\ Eliane El Badaoui \\ EconomiX - University Paris 10 \\ Prudence Kwenda \\ University College Dublin \\ Eric Strobl \\ Ecole Polytechnique Paris and IZA \\ Frank Walsh \\ University College Dublin
}
Discussion Paper No. 6604
May 2012

IZA

P.O. Box 7240

53072 Bonn

Germany

Phone: +49-228-3894-0
Fax: +49-228-3894-180
E-mail: iza@iza.org

Any opinions expressed here are those of the author(s) and not those of IZA. Research published in this series may include views on policy, but the institute itself takes no institutional policy positions.

The Institute for the Study of Labor (IZA) in Bonn is a local and virtual international research center and a place of communication between science, politics and business. IZA is an independent nonprofit organization supported by Deutsche Post Foundation. The center is associated with the University of Bonn and offers a stimulating research environment through its international network, workshops and conferences, data service, project support, research visits and doctoral program. IZA engages in (i) original and internationally competitive research in all fields of labor economics, (ii) development of policy concepts, and (iii) dissemination of research results and concepts to the interested public.

IZA Discussion Papers often represent preliminary work and are circulated to encourage discussion. Citation of such a paper should account for its provisional character. A revised version may be available directly from the author. 
IZA Discussion Paper No. 6604

May 2012

\section{ABSTRACT}

\section{The Formal Sector Wage Premium and Firm Size for Self-employed Workers}

We develop a model where formal sector firms pay tax and informal ones do not, but informal firms risk incurring the penalty associated with non-compliance. Workers may enter selfemployment or search for jobs as employees. Workers with higher managerial skills will run larger firms while workers with lower will manage smaller firms and will be in self-employment only when they cannot find a salary job. For these workers self-employment is a secondary/informal form of employment. The Burdett and Mortensen (1998) equilibrium search model turns out to be a special case that we amend by incorporating taxes and a penalty for non-payment of taxes. Our model is also consistent with some of the empirical literature in that the informal wage penalty does appear to be limited to low wage/skill workers while firm size is an important determinant of the employee formal sector premium. We test theoretical predictions using empirical evidence from Mexico and find that firm size wage effects for employees and self-employed workers are broadly consistent with the model.

JEL Classification: J31, O17

Keywords: $\quad$ informality, self-employment, Burdett and Mortensen model

Corresponding author:

Frank Walsh

School of Economics

University College Dublin

Belfield, Dublin 4

Ireland

E-mail: frank.walsh@ucd.ie 


\section{Introduction ${ }^{1}$}

Many of the earlier empirical studies comparing the wages of formal and informal sector workers suggest that informal sector workers, even if equally productive, are typically paid less than their formal sector counterparts. ${ }^{2}$ A number of explanations have been offered in this regard, mostly based on a segmented view of the labour market. ${ }^{3}$ However, more recently the evidence has been much more mixed. Cunningham and Maloney (2001) suggest that there may be an upper tier and lower tier of informal enterprises. Marcouiller, Ruiz and Woodruff (1997) find a wage premiums associated with informal work in Mexico but not in other countries while Günther and Launov (2011) find evidence of both competitive and segmented labour markets in the formal sector of Côte d'Ivoire. In other instances the existence of a wage penalty may depend on gender (Tansel, 2000), the level of education (Gong and van Soest, 2002), both firm-size and unobserved ability (Falco et al (2011), firm size El Badaoui et al, 2010 - EB from now on - ) or on the point in the wage distribution (Tannuri Pianto and Pianto, 2002, and Bargain and Kwenda, 2011). In other studies any payment differential can be entirely explained by unobserved heterogeneity (Pratap and Quintin, 2005). Considering the wide range of evidence overall, it is perhaps best to conclude that, if anything, there is a good deal of heterogeneity in the size of the informal premium/penalty and that for different groups of workers, as suggested by Fields (2007), the reality may be very diverse in that

\footnotetext{
${ }^{1}$ The introduction and data description draw on El Badaoui, Strobl and Walsh (2009) and El Badaoui, Strobl and Walsh (2010)

2 See, for example, Mazumdar (1981), Heckman and Hotz (1986), Roberts (1989), Pradhan and van Soest (1995), Tansel (1999), and Gong and van Soest (2002).

${ }^{3}$ For instance, the presence of barriers to entry into the formal sector could pose a possible cause, so that working in the informal sector is associated with a negative wage premium even for equally productive workers; see Fields (1975) and Mazumdar (1975).
} 
the desirability of informal sector employment in terms of remuneration depends on the segment of the labour market in question.

In this paper we develop a model that captures this heterogeneity and look for empirical support using micro data from Mexico. More specifically, we develop a model where self-employment arises as the most desirable outcome for workers with high managerial ability while the existence of search frictions means that self-employment emerges as a secondary, undesirable outcome for workers with low managerial ability. These low ability workers would prefer employment to self employment but are unable to find a job. As in EB informality is defined at the firm's level, and the firm's choice of whether to be formal or informal is endogenised. While we model managerial ability and the flow of workers into self-employment, the distinctive feature of the model is that these self-employed managers create jobs in an environment with search frictions. These frictions imply that salaried jobs may not be readily available, so that some workers who would prefer to be employed will enter self-employment, and also that wage dispersion will emerge among similar employees. A formal sector premium, which is identical to a firm size premium, emerges in equilibrium for employees. Self-employed managers of large formal firms also earn premiums, which are just a return to managerial ability.

Our main theoretical results are established in a general model where large firms are assumed to pay higher wages but the reason why is not specified. The Burdett and Mortensen (1998) equilibrium search model turns out to be a special case that we amend, for illustrative purpose, by incorporating taxes and a penalty for non-payment of taxes. In this example a firm size premium emerges endogenously and we can solve the model 
explicitly, illustrating the results. As in the Lucas (1976) span of control framework, workers differ in their relative productivity in employment and self-employment (managing a firm). ${ }^{4}$

One should note that our theoretical model follows a growing body of literature that uses search models to analyse the informal sector. For instance, Albrecht et al. (2009) extend the Mortensen and Pissarides (1994) matching model to incorporate a selfemployed informal sector where there is heterogeneity in workers' productivity in that more productive workers may opt to wait for a formal sector job, while others may select into the informal sector. Ulyssea (2010) develops a matching model incorporating key institutional features of the Brazilian economy and conducts policy simulations. Also, Boeri and Garibaldi (2006) develop a matching model with supervision where workers in the informal sector cannot avail of unemployment benefits, and show that matches found not paying tax are dissolved. Their model suggests that policies aimed at reducing the size of the shadow economy may increase unemployment. Alternatively, Fugazza and Jacques (2004) incorporate psychic costs as part of the costs of being in the informal economy in a matching model where workers direct their search at informal sector firms ${ }^{5}$.

Our model is also consistent with some of the empirical literature discussed earlier in that the informal wage penalty does appear to be limited to low wage/skill workers while firm size is an important determinant of the employee formal sector premium. Using information on firm size in a sample of employees and self-employed workers in Mexico we test the predictions of our model more directly. In this regard we assume that

\footnotetext{
${ }^{4}$ Rauch (1991) and Amaral and Quintin(2006) and Blau (1985) develop models where workers with higher managerial ability select into self-employment in a developing country context. There are no search frictions in these models.

${ }^{5}$ Bosch (2006) and Bosch and Maloney (2006) look at the effect of an informal sector on patterns of job creation and job destruction.
} 
if we observe a self-employed worker in a firm with more than one person in the firm this is an indicator of some managerial ability, while if we observe a large number of low-skill low-wage self-employed workers in one person firms, this is consistent with a residual sector where low-skill worker with low managerial ability remain in self-employment not by choice but because waged employment opportunities are rationed. To provide evidence that low-skill self-employed workers in one-person firms are in a secondary sector we compare their wages with similar employed workers to see if there is a wage premium. Indeed the evidence unearthed from the Mexican data generally supports the predictions of our model.

The remainder of our paper is organized as follows. In the next section we present our theoretical model. In Section III we outline the Burdett-Mortensen model as a specific example of our framework. Empirical support for the predictions of our model is provided in Section IV. Concluding remarks are given in the final section.

\section{The Model}

We will assume that worker types are ordered according to their productivity in self-employment. That is type 0 has the lowest productivity parameter $\left(p_{0}\right)$, type 1 the second lowest $\left(p_{I}\right)$ and so on up to the highest type $z$ workers. There is a mass $L_{i}$ of type $i$ workers in the economy where the total mass of workers is $L=\sum_{i=0}^{z} L_{i}$. Workers can be unemployed, self-employed or in employment. Since we shall focus on a stationary equilibrium we suppress the time subscripts to avoid clutter. Employees and the selfemployed may be in formal or informal firms. While each worker type differs in their 
productivity as a manager, all workers are equally productive as employees. ${ }^{6}$ We will refer to firms managed by a type $i$ worker as "type $i$ firms" and firms with only the manager employed as "own-account firms" from now on. There is free entry of firms, that is, any worker can choose to enter self-employment at any time.

While there are different reasons for firms to choose whether to be formal or informal in the model we present here, formal sector firms pay tax and informal ones do not, but informal firms risk incurring the penalty associated with non-compliance. Smaller firms who are more costly to monitor are less likely to be caught and so more likely to be in the informal sector. There are of course other reasons for being in the informal sector (see Era Dabla-Norris et al., 2006, for a more detailed discussion). For example, it may be that certification is important for a self-employed professional or tradesman so that particular types of small firms such as doctors and lawyers etc. will be in the formal sector for this reason. Access to capital is also easier for formal firms, as seen in Amaral and Quentin (2005) and other studies. At the same time, it may be that an inefficient bureaucracy imposes costs on the formal sector so some firms will go informal. Here we follow $\mathrm{EB}^{7}$ and introduce a tax rate $t$ on wage income that is paid by firms. We start with a general model where there is a positive and continuous relationship between a firm's employment $n$ and the wage $w, n(w)$, in a stationary equilibrium, but initially do not specify why this positive relationship exists. Firms have

\footnotetext{
${ }^{6}$ In reality of course there will be differences in workers productivity in employment and this may differ across formal status. In particular Albrecht et al (2009) outline a version of the Mortensen Pissarides matching model where it is assumed that workers have the same ability in self-employment but workers differ in skills which are used in employment. Since skills are only useful in employment low skill workers prefer not to incur the cost of searching for employment in equilibrium and prefer self-employment even though this is a low wage sector.

${ }^{7}$ Much of the following passage is taken straight from EB who discuss the large literature that equates informality with small firms in more detail. Note that a fundamental difference with EB is that selfemployment was not modelled explicitly in this earlier contribution.
} 
the production function $p_{i} q(n)$ where $p_{i}$ is the productivity of the manager. We assume that $q_{n}(n)>0$ and $q_{n n}(n)<0$. There is a tax rate $t$ on wages and a Poisson arrival rate of negative shocks, $\delta$, which will destroy the firm. If the firm is destroyed the selfemployed manager can set up a new firm but the setup cost is a fraction $\gamma$ of the value of a firm to that manager. The Poisson arrival rate of tax inspectors is a positive function of the number of employees at the firm, $\Theta[n(w)]$. If firms are caught not paying their taxes they are punished and must pay a fine according to the function. $\Omega[w \operatorname{tn}(w)]$, which is increasing in the per period tax bill $w \operatorname{tn}(w)$.

The flow of profits in self-employment for a manager of type $i$ managing a defaulting $(d)$ or compliant $(c)$ firm in a stationary equilibrium at any wage $w$ are:

$$
\begin{aligned}
& \pi_{i}^{d}=p_{i} q[n(w)]-w n(w)-\Theta[n(w)] \Omega[w \operatorname{tn}(w)] \\
& \pi_{i}^{c}=p_{i} q[n(w)]-w(1+t) n(w)
\end{aligned}
$$

Defaulting firms pay the wage net of tax but incur a cost if they are caught defaulting, the probability of which depends on the number of workers, while compliant firms do not incur this cost but pay the tax.

The flow value of the firm for defaulting or compliant self-employed managers is respectively.

$$
\begin{aligned}
& r V_{i}^{d}(w)=\pi_{i}^{d}+\lambda \int_{\underline{w}}^{\bar{w}}\left\{\max \left[V_{i}^{d}(w), E(x)\right]-V_{i}^{d}(w)\right\} d F(x) \\
& -\delta \max \left\{\gamma V_{i}^{d}(w),\left[V_{i}^{d}(w)-U_{i}\right]\right\} \\
& r V_{i}^{c}(w)=\pi_{i}^{c}(w)+\lambda \int_{\underline{w}}^{\bar{w}}\left\{\max \left[V_{i}^{c}(w), E(x)\right]-V_{i}^{c}(w)\right\} d F(x) \\
& -\delta \max \left\{\gamma V_{i}^{c}(w),\left[V_{i}^{c}(w)-U_{i}\right]\right\}
\end{aligned}
$$


The flow value of the firm, where $r$ is the discount rate, is the dividend stream plus any capital gain/loss in the value of the firm. The dividend stream is the flow of profits and the capital gain term comes from employment opportunities and from the arrival rate of negative shocks that destroy the firm. The, for now, exogenously given job offer distribution is $F(w)$. This gives us the probability that any offer received has a wage $w$ or less. We make the simplifying assumption that the stream of job offers is the same for an employee, a self-employed worker or an unemployed worker. All workers receive job offers at a Poisson arrival rate $\lambda$. The gain associated with an employment offer with value $E(w)$ is $\left[E(w)-V_{i}^{j}\right]$ where $j \in(d . c)$, or zero for offers worse than the current state. ${ }^{8}$ We get the expected value of offers by integrating over the wage offer distribution. If a negative shock arrives the self-employed worker can either set up a new firm in selfemployment in which case they incur a sunk cost which is a fraction of the value of the firm, $\gamma V_{i}^{j}$, and incur a capital loss of this amount, or else enter unemployment which has a value $U_{i}$. Entering unemployment from self-employment implies a loss of $-\left(V_{i}^{j}-U_{i}\right){ }^{9}$ Unemployment has the flow value:

$$
r U=b+\lambda \int_{\underline{w}}^{\bar{w}}[\max \{E(w), E(x)\}-U] d F(x)
$$

\footnotetext{
${ }^{8}$ Since all workers have the same productivity in employment the value of a job offer does not depend on the workers type.

${ }^{9}$ It is worth noting at this stage that if we brought the stream of profits to one side where $j \in(d . c)$ then: $r V_{i}^{j}(w)-\lambda \int_{\underline{w}}^{\bar{w}}\left\{\max \left[V_{i}^{j}(w), E(x)\right]-V_{i}^{j}(w)\right\} d F(x)+\delta \max \left\{\gamma V_{i}^{j}(w),\left[V_{i}^{j}(w)-U_{i}\right]\right\}=\pi_{i}^{j}(w)$
}

Since the three terms on the left hand side are monotonically increasing in $V_{i}^{j}(w)$ it must be that $\operatorname{sign}\left[\frac{d V_{i}^{j}(w)}{d w}\right]=\operatorname{sign}\left[\frac{d \pi_{i}^{j}}{d w}\right]$. 
The stream of benefits is $b$ and the worker has the possibility of a capital gain if a job offer arrives. Self-employment is preferred to unemployment if the expected value of self-employment net of the setup cost of a firm is better than the expected value of unemployment:

$$
(1-\gamma) \max \left(V_{i}^{d}, V_{i}^{c}\right)>U
$$

The flow value of employment in any job is:

$$
\begin{aligned}
& r E_{i}(w)=w+\lambda \int_{\underline{w}}^{\bar{w}}\left[\max \{E(w), E(x)\}-E_{i}(w)\right] d F(x) \\
& \left.-\delta\left[E_{i}(w)-\max \left\{(1-\gamma) V_{i}^{d},(1-\gamma) V_{i}^{c}, U_{i}\right)\right\}\right]
\end{aligned}
$$

This is the flow value of the wage plus the value of higher wage job offers times the arrival rate of such offers integrated over the job offer distribution, plus the arrival rate of negative shocks that lead to job loss times the capital loss from losing a job. The latter is the difference between the value of the current state and the maximum of the value of unemployment and the value of self-employment (net of the cost of setting up a firm).

\section{Proposition One:}

Higher productivity firms offer higher wages than lower productivity firms. ${ }^{10}$ That is, if there are two firms managed by type $i$ and $k$ managers respectively where $p_{i}>p_{k}$, then $w_{i} \geq w_{k}$ for all wages paid by type $i$ and type $k$ firms.

\section{Proof in Appendix 1}

\footnotetext{
${ }^{10}$ Burdett and Mortensen (1998) p268. Show this to be true in their model which we will use as an example later.
} 
We assume that there is a stationary equilibrium where there is a continuous positive relationship between the number of employees and the wage rate $n(w)$. We will denote the tax bill as $B=w \operatorname{tn}(w)$ for shorthand.

Proposition Two: If the elasticity of punishment with respect to the tax bill is greater than or equal to unity, $\frac{\partial \Omega(B)}{\partial B} \frac{B}{\Omega} \geq 1$, and there are some compliant and some noncompliant firms of a given type in equilibrium, then there will be a cut-off point in firm size below which all firms will default on their taxes, and above which firms will be compliant. In other words, we will have a wage distribution with small low-wage firms in the informal sector and large high-wage firms in the formal sector. Proof in Appendix 1

Propositions One and Two establish that higher productivity firms pay higher wages and that there will be a cut-off point for firm size and the wage above which firms will choose to be compliant. Large, high-wage firms will be compliant and small, low-wage firms will be non-compliant. This was also the case in EB where there was no difference in productivity across firms and where self-employment was not modelled explicitly. We will denote the lowest and highest wage paid by each firm type in equilibrium respectively as $\underline{w}_{i}$ and $\bar{w}_{i}$.

\section{Proposition Three:}

Workers with the lowest managerial ability would prefer any job to self-employment. Proof in Appendix 1 
Proposition Three shows that workers with the lowest managerial ability will be in a secondary informal sector in the sense that any job would be better than their current state. If unemployment benefits are sufficiently low (4) will hold for the lowest ability group and this group will prefer self-employment to unemployment. But if benefits are sufficiently high (4) will not hold and this group will choose unemployment over selfemployment.

Next we assume that an own-account worker has labour supply $n^{o}$ so that output for an own-account worker of type $i$ is $p_{i} q\left(n^{o}\right)$. If income of own-account workers is liable for tax and the assumptions of Proposition Two hold, own-account firms will be non-compliant since they are the smallest firms. Of course any self-employed worker can choose to be either a manager or an own-account worker. For simplicity we assume that the only tax is a payroll tax, so that profits are not taxed. This means that own-account firms do not pay tax and have a profit stream:

$$
\pi_{i}^{d}\left(n_{0}\right)=p_{i}\left(n_{0}\right)
$$

\section{Proposition Four:}

As long as some firms are larger than own-account firms, the highest ability managers will prefer self-employment to any employment offer.

\section{Proof in Appendix 1}

While Proposition Three established that workers with the lowest managerial ability would prefer any job to self-employment, Proposition Four establishes that there will be a group of workers (those with the highest managerial ability) who prefer selfemployment to any job offer. We note that this implies that if there are more than two ability groups we will have a lot of heterogeneity across the pool of self-employed 
workers. In particular there will be a low ability group who would prefer any job to selfemployment, a high ability group who would not accept any job and possibly an intermediate ability groups who (given that there are good and bad job offers) would accept some jobs but not others.

\section{The Burdett Mortensen model as an example}

Below we summarise labour market flows and then derive the equilibrium labour supply curve and wage offer distribution using the equilibrium search model outlined in Burdett and Mortensen (1998) [BM from now on] . This model serves as an example where a positive relationship between firm size and wages emerges endogenously in equilibrium and where we can solve the model explicitly. We begin by deriving the labour supply curve in a model where there are search frictions and workers receive on the job offers. ${ }^{11}$ We define $m_{i}$ as the mass of type $i$ self-employed workers who employ others and $s_{i}$ as the mass of type $i$ self-employed own-account workers. This means that a mass of $m_{i}+s_{i}=u_{i} L_{i}$ type $i$ workers are in self-employment, where $u_{i}$ is the selfemployment rate for type $i$ workers. There is random matching so that any job offer is equally likely to come from any firm irrespective of the firm's size. ${ }^{12}$ The distribution of wage offers which we will solve for is $F(w)$. BM assume $r=0$ in their derivation of the labour supply curve and we follow this assumption. The other assumptions and parameter definitions from the previous section continue to hold. For simplicity we will assume that unemployment benefits are low enough so that the lowest ability group choose to be

\footnotetext{
${ }^{11}$ See Mortensen (2003) and Burdett and Mortensen (1998) for a detailed derivation of the labour supply curve.

${ }^{12}$ See Manning (2003) pp. 284-286 for a discussion on the matching technology.
} 
in self-employment and thus there will be no unemployed workers in equilibrium. ${ }^{13}$ In particular this means that $(1-\gamma) \max \left(V_{i}^{d}, V_{i}^{c}\right)>U$ for all worker types. Self-employed workers incur the cost of setting up a firm when they lose a job or when their existing firm receives a negative shock. Since this cost is sunk, any job offer with a wage higher than self-employment profits would be accepted by this worker. In a stationary equilibrium inflows and outflows to self-employment of each worker type are equal, implying the following relationship between inflows and outflows from selfemployment: $\lambda\left[1-F\left(\pi_{i}\right)\right] u_{i}=\delta\left(1-u_{i}\right)$. This implies that the self-employment rate is:

$$
u_{i}=\frac{\delta}{\delta+\lambda\left[1-F\left(\pi_{i}\right)\right]}
$$

The share of wage offers which fall below the self-employment profit a type $i$ worker can earn is $F\left(\pi_{i}\right)$. If $N_{i}(w)$ is aggregate employment of type $i$ workers at wage $w$ or less, stationarity ensures that the outflows (the separation rate plus the flow of job offers received from higher wage firms, times the stock) and inflows (the number of offers less than $w$ accepted by self-employed workers of this type) to this stock are equal, i.e.:

$$
\dot{N}_{i}=\{\delta+\lambda[1-F(w)]\} N_{i}(w)-\lambda\left[F(w)-F\left(\pi_{i}\right)\right] u_{i} L_{i}=0
$$

We can solve for employment of type $i$ workers earning $w$ or less, which is the employment rate for this group, $1-u_{i}$, times the wage distribution of this group, $G_{i}(w)$, times the population of workers of this type, $L_{i}$ :

$$
N_{i}(w)=\left(1-u_{i}\right) G_{i}(w) L_{i}=\frac{\lambda\left[F(w)-F\left(\pi_{i}\right)\right] u_{i} L_{i}}{\delta+\lambda[1-F(w)]}
$$

\footnotetext{
${ }^{13}$ This assumption fits well with the stylized facts in countries like Mexico, as discussed in the next section, but less so with countries (South Africa for example) where unemployment benefits exist together with significant unemployment and small informal sectors (see for instance El Badaoui et al., 2008)
} 
Solving for $G_{i}(w)$

$$
G_{i}(w)=\frac{N_{i}(w)}{\left(1-u_{i}\right) L_{i}}=\frac{\delta\left[F(w)-F\left(\pi_{i}\right)\right]}{\{\delta+\lambda[1-F(w)]\}\left[1-F\left(\pi_{i}\right)\right]}
$$

Total per firm inflows of type $i$ workers to firms offering a wage $w$ at any point in time are:

$$
\begin{aligned}
& h_{i}(w)=\lambda \frac{L_{i}}{M}\left\{u_{i}+G_{i}(w)\left(1-u_{i}\right)\right\}=\lambda \frac{L_{i}}{M}\left\{\frac{\delta+\lambda G_{i}(w)\left[1-F\left(\pi_{i}\right)\right]}{\delta+\lambda\left[1-F\left(\pi_{i}\right)\right]}\right\} \\
& \text { or if } w<\underline{w}_{i} \text { then } h_{i}(w)=0
\end{aligned}
$$

The mass of firms is $M=\sum_{i=1}^{n} m_{i}$. Each worker can expect to receive $\frac{\lambda}{M}$ offers at each point in time from each firm ${ }^{14}$. A fraction $u_{i}$ of the population of type $i$ workers will be self-employed and will accept all wage offers they receive from firms offering $w$, as long as $w$ is greater than their reservation wage. ${ }^{15}$ Also a fraction $1-u_{i}$ of type $i$ workers are in employment and $G_{i}(w)$ of them earn no more than $w$. These workers will accept offers of $w$ and also represent an inflow to a firm paying a wage $w .{ }^{16}$ The separation rate at any firm for any worker type: $d(w)$ is the sum of the job destruction rate $\delta$ plus the arrival rate of offers to each worker times the probability the offer comes from a higher wage firm: $\lambda[1-F(w)]:$

$$
d(w)=\delta+\lambda[1-F(w)]
$$

The separation rate times employment equals inflows per firm in a stationary equilibrium, so the labour supply of type $i$ workers is:

\footnotetext{
${ }^{14}$ Because of random matching each offer is equally likely to come from any firm.

${ }^{15}$ We note that since a worker of type $i$ can always earn $p_{i}$ as an own-account worker their reservation wage must be greater than or equal to $p_{i}$.

${ }^{16}$ The remaining $\lambda L H_{i} G_{i}(w)\left(1-u_{i}\right)$ offers will be received by workers who already earn more than $\mathrm{w}$ and would be rejected.
} 


$$
\begin{aligned}
& n_{i}(w)=\frac{h_{i}(w)}{d(w)}=\frac{\lambda L_{i}}{M}\left\{\frac{\delta+\lambda G_{i}(w)\left[1-F\left(\pi_{i}\right)\right]}{\left\{\delta+\lambda\left[1-F\left(\pi_{i}\right)\right]\right\}\{\delta+\lambda[1-F(w)]\}}\right\}=\frac{L_{i}}{M} \frac{\delta \lambda}{\{\delta+\lambda[1-F(w)]\}^{2}} \\
& \text { note } \frac{L_{i}}{M}=\frac{L_{i}}{\sum_{i=1}^{n} m_{i}} \quad \text { or if } w<\underline{w}_{i} \text { then } \mathrm{n}_{i}(w)=0
\end{aligned}
$$

Equation (13) gives the labour supply of type $i$ workers to a firm paying a wage $w$. To get total labour supply to any firm we aggregate over the three worker types:

$$
\begin{gathered}
n(w)=\sum_{i=1}^{n} n_{i}(w)=\sum_{i=1}^{j} \frac{L_{i}}{M} \frac{\delta \lambda}{\{\delta+\lambda[1-F(w)]\}^{2}}=\frac{L}{M} \frac{\delta \lambda}{\{\delta+\lambda[1-F(w)]\}^{2}} \\
\text { if } w<\underline{w}_{i} \text { then } \mathrm{n}_{i}(w)=0
\end{gathered}
$$

\section{The equilibrium wage distribution}

We assume that there are three worker types: 0,1 and 2 where as before a higher number indicates higher managerial ability. We assume output increases at a constant rate with additional workers and that own-account labour supply equals unity: $n_{0}=1$. That is the profitability of an own-account worker is:

$$
\pi_{i}\left(n_{o}\right)=p_{i}
$$

The production function for a self-employed worker hiring others is:

$$
q_{i}\left[p_{i}, n\right]=p_{i} n
$$

We assume that the sunk cost of becoming an own-account worker is the same fraction of profits $\gamma$ as the cost of becoming an employer.

To solve the model explicitly we follow EB and assume the Poisson arrival rate of tax inspectors is a constant $\mu$ times employment to the power of a constant $\beta$ so that 
large firms are more likely to be caught defaulting: $\Theta[n(w)]=\mu n(w)^{\beta}$. We specify the penalty for defaulting as $x$ times the firm's per period tax bill: $\Omega[w \operatorname{tn}(w)]=x w \operatorname{tn}(w)$. To save on notation we define $s=x \mu$ as the parameter that when multiplied by employment to the power of $\sigma=\beta+1$ determines the expected punishment for defaulters at any point in time. In this case from (2) $V_{i}^{d}=V_{i}^{c}$ implies:

$$
n^{*}=s^{\frac{1}{1-\sigma}}
$$

We can use the expression for labor supply (14) in (17) to calculate the cut-off value of the wage offer distribution below which firms will be defaulting: ${ }^{17}$

$$
F^{*}=\frac{\delta+\lambda}{\lambda}-\sqrt{\frac{\delta}{\lambda} \frac{L}{M} s^{\frac{1}{\sigma-1}}}
$$

Appendix 2 spells out the detail on how we solve the model explicitly. Clearly the form of the equilibrium distribution depends on the parameter assumptions. We assume a set of values on the tax and punishment parameters such that some firms are compliant and others non-compliant in equilibrium. The equilibrium wage offer distribution is shown in Figure 1 where we differentiate the offers made by different types of employers. The parameter values assumed in Figure 1 are given in Table 4 of Appendix $3 . \quad$ We see in Figure 1. that the distribution is continuous over two regions with a jump at the wage where firms choose to be compliant. The high ability employers offer higher wages than the intermediate ability employers in line with Proposition One. The smallest firms managed by intermediate ability employers are non-compliant and higher wage firms with employment levels greater than implied by (17) are compliant in line with Proposition Two. We note from Figure 1 that the lowest ability workers will never hire

\footnotetext{
${ }^{17}$ It is worth noting that even with a general production function $\mathrm{y}=\mathrm{y}(\mathrm{n})$, where $\mathrm{y}$ is output, equation (17) and (18) will hold.
} 
others in equilibrium and will accept any job offer in line with Proposition Three. As we would expect from Proposition Four the highest ability group are all self-employed.

\section{Empirical Evidence}

Our theoretical model suggests a number of hypothesis which we can seek to test empirically. More precisely, small firms will be informal and large firms formal.

Additionally, both employees and the self-employed will earn a firm size wage premium which will reflect ability for the self-employed but rents for employees. The model also predicts that self-employed workers in the smallest firms will be the residual category and thus should have lower wages than all others.

The data comes from the Mexican National Occupation and Employment Survey (ENOE) conducted by the Instituto Nacional de Estadistica, Geographica Informatica (INEGI). This is a quarterly survey where workers are observed at most five times over a five-quarter period. We use data from the second quarter 2005 to the third quarter 2008. We restrict our sample to urban men aged 15 to 65 years, not engaged in any form of education, and in full time employment in the private sector. We focus on men to avoid any selection issues associated with differences in participation rates in employment and self-employment. We include only private sector workers, which excludes unpaid family workers and public sector employees for similar reasons.

The question we have for earnings in the questionnaire is "what are the earnings from main occupation?” and the payment periods are provided as monthly, every 15days, every week, per day and other payment period. These are used to convert all incomes to calculate a weekly gross wage for the primary job. Usual weekly hours are 
used as a control variable in the analysis. It would be desirable to distinguish between wages and profits for the self-employed workers - the information on monthly earnings does not allow this distinction hence in this paper we are comparing self-employment income to formal sector wages on the basis of weekly earnings.

Summary statistics for the variables used in the analysis are presented in Tables S1 and S2 in Appendix 3, for the full sample and by self- employment / employee status. This also gives us the proportion of workers in each firm size category by formal vs. informal and self-employment vs. employee categories. The self-employed are older (41.9 years compared to 33.7), less likely to be single (11\% compared to $26 \%$ ) and work fewer hours per week (47.8 compared to 50.4). While there is little difference in years of education (7.33 and 8 years respectively), we note from Table S3 that when we look at average years education by self-employment vs. employee and by firm size that there is a noticeable increase in years as firm size category increases, particularly for the selfemployed. ${ }^{18}$ This indicates that the assumption that higher ability workers manage larger firms may be reasonable.

Table 1 shows the results of a probit regression (clustered by individuals) on informal status controlling for a large number of other factors. ${ }^{19}$ There are two separate regressions, the first column for self-employed workers and the second for workers who are employees. The excluded category is firms with one worker for the self-employed and firms with 2-5 employees for employees (note that workers in a firm with only one

\footnotetext{
${ }^{18}$ Table S3 shows a less pronounced but nevertheless a clear increase for employees. To make the model tractable the theoretical model assumes skills used in employment are equal across workers , this assumption means the model makes no meaningful prediction on the equilibrium relationship between firm size and ability for employees.

${ }^{19}$ In all regressions we include wave dummies, years of education and its squared value, age and its squared value, gender, marital status dummies, and one digit industry and occupation dummies.
} 
employee must be self-employed so there are no employees in firms with one worker). Within both groups the reported coefficient which is the marginal probability of being informal is negative for all groups and typically falls substantially as firm size increases. The exception is that the probability of being informal for self-employed workers in firms with $11-15$ workers is $2.7 \%$ lower than own-account workers while it is only $1.1 \%$ lower for self-employed workers in firms with 11-15 workers. However, when we move to firms greater than 51 workers the probability of being informal is $13.5 \%$ lower than for own-account workers. Overall there seems to be strong support for the prediction that larger firms are more likely to be formal. This is consistent with Proposition Two.

Table 2 provides the results from regressions with the log weekly wage as the dependent variable. The regression in the first column of Table 2 includes dummies for formal employees, formal self-employed workers and informal employees. That is informal self-employed are the excluded category. As can be seen, in Mexico the selfemployed earn wage premia relative to employees. In particular self-employed informal workers earn $21.8 \%$ more than informal employees and $4 \%$ more than formal employees. For both employees and the self-employed, earnings are higher than for their informal sector counterparts. Formal self-employed workers earn $11.3 \%$ more than informal selfemployed workers. This basic formulation is consistent with the evidence from the literature in Maloney (2004) or Marcouiller, Ruiz and Woodruff (1997) that selfemployed workers are not in a secondary sector.

The second column in Table 2 allows for the fact that firm size will act as a proxy for the formal premium if large firms are typically formal because of the fear of being caught. Higher wages for workers in larger firms are do not reflect the skill of the worker 
or a compensating differential for any other aspect of the job that is controlled for and are interpreted as rents. Firm size dummies for self-employed workers on the other hand are interpreted as returns to managerial ability. That is if there is a positive and increasing coefficient as we move to larger firms we interpret this as an indication that higher skilled managers run larger businesses and are paid more. There are six firm size categories (Own-account firms, 2-5, 6-10, 11-15, 16-50 and > 50). We exclude observations where firm size could not be established in all of the regressions. We see in the second column of Table 2 that in line with the assumptions underlying the model, wages increase progressively for employees as they move into larger firms and the same is true for selfemployed workers. Employees in all firm size categories (except the smallest firms) are better off than self-employed in the smallest firms. This stands in contrast to the results in the first column where self-employment emerges as the high wage sectors. When we interact with firm size self-employment is often only a high wage sector for those who employ others and this premium increases as the size of the firm managed increases.

Table 2 presents the results across firm size categories without controlling explicitly for formal/informal status. While this is in line with the theoretical model, as we noted earlier there are other plausible models of informality that do not imply that small firms will always be informal. In addition we only look at gross wages while EB show that differentiating between net and gross wage for formal and informal workers is an important factor in explaining the formal sector wage premium. Given these arguments Table 3 presents log weekly wage regressions for firm size categories by selfemployment/employment status and formal/informal status. The excluded category is own-account (one worker in the firm) informal self-employed workers. We will discuss 
the coefficients for self-employed workers initially. We note that for both formal and informal self-employed workers the coefficient on firm size is always positive, statistically significant and increasing with firm size. We also note that the coefficient on formal self-employed is always larger than for informal self-employed within each firm size category indicating that there is a formal premium for self-employed workers. As noted above this may be because firm size does not capture the effect of informality fully or simply the fact that we are looking at gross wages and formal workers would have a higher gross wage in equilibrium since the expected wage/profit (net of taxes for formal workers or penalties if caught defaulting for informal) are equal for formal and informal self-employed workers in equilibrium.

When we look at the firm size coefficients for employees, we see that while they are much smaller than for self-employed workers, they are always positive for formal employees and, with the exception of the smallest firm size category, statistically significant and increasing with firm size. That is formal sector employees who from the summary statistics in Appendix 3 account for just over 40\% of all workers are always better off than own-account self-employed workers and the size of this affect increases with firm size. The picture is less clear for informal employees. Employees in firms with less than ten workers earn about $17 \%$ less than own-account self-employed workers. From the summary statistics we see that informal employees account for about $31 \%$ of all workers and about $27 \%$ of this total is accounted for by employees in firms with less than ten workers. Informal employees in larger firms do earn premiums that increase with firm size relative to own-account self-employed workers. 
We can summarise how consistent the results described above are with the four propositions from the theoretical section. Proposition One says that more productive firms will pay more. The results described above are consistent with this. Managers of larger firms do have higher measured ability and larger firms pay more. Proposition Two predicts a wage distribution with small low wage informal firms and large formal high wage firms. Once again most of the evidence is consistent with this, Table 1 provides strong evidence of a positive relationship between firm-size and formality while results from the wage regressions in Tables 2 and 3 show that larger firms pay more.

Proposition Three suggests that workers with the lowest managerial ability will prefer any job to self-employment. If we accept that managers of the smallest firms are the lowest ability group of managers then the evidence from Table 3 suggests that selfemployed own account managers (who are the excluded category in the regression in Tale 3) would earn more in a job in a large informal firm or any formal firm. There are a substantial number of workers in small informal firms who earn less than the own account self-employed workers and this is not consistent with Proposition Three. That is while there is convincing evidence that low skilled managers would earn higher wages in many jobs, this is not true for jobs in small informal firms. Proposition Four suggests that the highest ability managers (those managing the largest firms) prefer their current state to any possible job offer. The regression results in Table 3 strongly support this proposition, self-employed managers of larger firms earn large premiums relative to all other workers and this premium is highest in the largest firms. 


\section{Conclusion}

To the best of our knowledge the model of the formal/informal sector we outline here is the first to combine heterogeneity in managerial ability with search frictions in the labour market, allowing for a richer set of outcomes where self-employment may be desirable or an undesirable but unavoidable state for different workers. Arguably this is an important contribution given the growing body of empirical evidence discussed in the introduction which shows that there is substantial heterogeneity in outcomes within the formal/informal sectors.

The model has clear empirical predictions which as discussed in the previous section are broadly supported by the data, namely firm size premiums for both employees and the self-employed and that small scale self-employed informal workers are stuck in an undesirable state while intermediate or larger scale managers are self-employed by choice rather than necessity. We note though that in contrast to the predictions of the model there are a substantial group of employees in small informal firms who earn less than self-employed own-account workers.

We acknowledge that firm size is unlikely to be the only determinant of informality or a perfect predictor of managerial ability for the self-employed but as the literature shows, it is a key predictor of these variables and the empirical evidence provides a good deal of support for the predictions of the model. 


\section{References}

Albrecht, J., L. Navarro and S. Vroman (2009) “The Effects of Labour Market Policies ina an Economy with an Informal Sector" The Economic Journal, 119, (July), 1105-1129

Amaral, P. S. and Quintin, E., 2006. A Competitive Model of the Informal Sector. Journal of Monetary Economics 53, 1541-1553.

Bargain, O. and Kwenda, P. (2011) "Earnings Structures, Informal Employment, and Self-Employment: New Evidence from Brazil, Mexico, and South Africa”, Review of Income and Wealth, 57, S100-S122, 2011.

Blau, D. (1985) Self-Employment and Self-selection in Developing Country Labor Markets, Sothern Economic Journal, Vol. 52, No. 2. pp. 351-363

Boeri, T., Garibaldi, P., 2006. "Shadow Sorting”. CEPR Discussion Paper No. 5487 (2006).

Bosch, M. (2006) "Job Creation and Job Destruction in the Presence of Informal Labour Markets”, CEP Discussion paper no. 761

---------and W.F. Maloney (2006) "Gross Worker Flows in the Presence of Informal Labor Markets. The Mexican Experience 1987-2002, CEP Working paper no. 753

Burdett K. and D. T. Mortensen (1998). "Wage Differentials, Employer size, and Unemployment” International Economic Review Vol. 392.

Cunningham, W. and W.F. Maloney, (2001) Heterogeneity in the Mexican Microenterprise Sector: An Application of Factor and Cluster Analysis ", Economic Development and Cultural Change, p.131-156.

El Badaoui, E., Strobl, E., Walsh, F., (2008) 'Is there an informal employment wage penalty? Evidence from South Africa'. Economic Development and Cultural Change, 56 (3):683-710.

El Badaoui, E., E. Strobl and F. Walsh (2010) 'The Formal Sector Wage Premium and Firm Size'. Journal of Development Economics, forthcoming

Era Dabla-Norris , Mark Gradstein, Gabriela Inchauste (2006) What causes firms to hide output? The determinantsof informality, Journal of Development Economics

Falco, P., A. Kerr, N. Rankin, J. Sandefur and F. Teal (2011) “The returns to formality and informality in urban Africa”, Labour Economics, 18, s23-s31

Fields, G. S. (1975), "Rural-urban migration, urban unemployment and underemployment, and job-search activity in LDC's”, Journal of Development 
Economics, 2(2), 165-87.

(2009) "Segmented Labor Market Models in Developing Countries" in Harold

Kincaid and Don Ross, The Oxford Handbook of the Philosophy of Economic Science,

Oxford University Press.

Fugazza, M., Jacques, J.F., 2004. Labor Market Institutions, Taxation and the Underground Economy. Journal of Public Economics 88, 395-418.

Ulyssea G. (2010) "Regulation of entry, labor market institutions and the informal sector, Journal of Development Economics 91, 87-99

Gong, X. and Van Soest, A. (2002). "Wage differentials and mobility in the urban labour market: a panel data analysis for Mexico”, Labour Economics, 9, pp. 513-529.

Günther, I. and A. Launov (2012) "Informal employment in developing countries: Opportunity or last resort” Journal of Development Economics, 97 88-98

Heckman, J. J. and Hotz, V.J. (1986), “An Investigation of the Labor Market Earnings of Panamanian Males: Evaluating the Sources of Inequality", Journal of Human Resources 21(4):507-542.

Lucas, R.E., 1978. On the Size Distribution of Business Firms. Bell Journal of Economics9, 508-523.

Maloney, W.F. (1998), “Are LDC labor markets dualistic?”, The World Bank. ........(2004)Informality Revisited, "World Development “ Vol. 32, No. 7, pp. 1159-1178

Fiess, N. M. and M. Fugazza, William F. Maloney (2010) “Informal self-employment and macroeconomic fluctuations” Journal of Development Economics, 91 pp 211-226

Marcouiller, D., Ruiz de Castilla, V. and Woodruff, C. (1997). "Formal Measures of the Informal-Sector Wage Gap in Mexico, El Salvador, and Peru," Economic Development and Cultural Change, 45(2), pp. 367-92.

Mazumdar, D. (1975), "The theory of share-cropping with labour market dualism”, Economica, London School of Economics and Political Science, vol. 42(167), p.p. 26171, August

Mazumdar, D. (1981), “The urban labor market and income distribution: A study of

McKenzie, D. and Y. Seynabou Sakho (2010) "Does it pay firms to register for taxes? The impact of formality on firm profitability, Journal of Development Economics ,(91) pp 15-24.

Mortensen, D.T., Pissarides, C.A., 1994. Job Creation and Job Destruction in the Theory of Unemployment. Review of Economic Studies 61, 397-415. 
Pradhan, M. and Van Soest, A. (1995), "Formal and informal sector employment in urban areas of Bolivia”, Labour Economic, 2 (1995) 275-297”, Washington, Banque Mondiale.

Pratap, S., Quintin, E. (2006) Are Labor Markets Segmented in Developing Countries? A Semiparametric Approach. European Economic Review 50, 1817-1841.

Rauch, J.E., 1991. Modelling the informal sector formally. Journal of Development Economics 35, 33-47.

Roberts, B. R. (1989), “The Other Working Class: Uncommitted Labor in Britain, Spain, and Mexico”, pp. 352-72 in Cross-National Research in Sociology, edited by M. L. Kohn. Newbury Park, CA: Sage Publications.

Teal, F. (2011) “The price of labour and understanding the causes of poverty”, Labour Economics, 18, s7-s15

Tannuri-Pianto, M. E., Pianto, D. (2002), “Informal employment in Brazil - a choice at the top and segmentation at the bottom: a quantile regression approach”, Mimeo.

Tansel, A. (1999), "Formal versus informal sector choice of wage earners and their wages in Turkey”, Paper 9927, Economic Research Forum.

Tokman, V. (1982), "Unequal Development and the Absorption of Labour: Latin America 1950-1980”, CEPAL Review 17:121-33

Tybout, J., 2000. Manufacturing Firms in Developing Countries: How Well Do They Do and Why?. Journal of Economic Literature 38, 11-44. 


\section{Appendix 1: Proof of Propositions}

\section{Proof of Proposition One:}

From (2) a firm will maximize the value of the firm by maximizing the stream of profits. In equilibrium if a type $i$ manager pays a wage $w_{i}$ and a type $k$ manager a wage $w_{k}$. We assume that $j 1$...j4 in (19) below are all either equal to $d$ or $c$, denoting whether the firm is compliant or defaulting:

$$
\pi_{i}^{j 1}\left[p_{i}, w_{i}, n\left(w_{i}\right)\right] \geq \pi_{i}^{j 2}\left[p_{i}, w_{k}, n\left(w_{k}\right)\right]>\pi_{k}^{j 3}\left[p_{k}, w_{k}, n\left(w_{k}\right)\right] \geq \pi_{k}^{j 4}\left[p_{k}, w_{i}, n\left(w_{i}\right)\right]
$$

We define $\pi_{i}^{j 1}$ as the level of profit for the optimal choice of wage and c or $d$ of a type $i$ firm and $\pi_{k}^{j 3}$ as the optimal choice for a type $k$ firm ${ }^{20}$. The first inequality in (19) will hold irrespective of whether $j 2$ equals $j 1$ or not since the firm can do no better than the optimal choice. Given this we set $j 2$ equal to $j 3$ which ensures that given that we assume that: $p_{i}>p_{k}$, the second inequality will hold. Since $\pi_{k}^{j 3}\left[p_{k}, w_{k}, n\left(w_{k}\right)\right]$ is the level of profit for an optimal choice of wage for this firm type, the third inequality will hold irrespective of whether $j 4$ equals $j 3$ or not. Given this we set j4 equal to $j 1$. We can rearrange (19) as follows:

$$
\pi_{i}^{j 1}\left[p_{i}, w_{i}, n\left(w_{i}\right)\right]-\pi_{k}^{j 4}\left[p_{k}, w_{i}, n\left(w_{i}\right)\right] \geq \pi_{i}^{j 2}\left[p_{i}, w_{k}, n\left(w_{k}\right)\right]-\pi_{k}^{j 3}\left[p_{k}, w_{k}, n\left(w_{k}\right)\right]
$$

Since $j 1=j 4$ and $j 2=j 3$ equations (2) imply that (20) can be rewritten as:

$$
\left(p_{i}-p_{k}\right) y\left[n\left(w_{i}\right)\right] \geq\left(p_{i}-p_{k}\right) y\left[n\left(w_{k}\right)\right]
$$

This implies that $n\left(w_{i}\right) \geq n\left(w_{i}\right)$ which implies that $w_{i} \geq w_{k} \square$

\footnotetext{
${ }^{20}$ So for example if it is optimal for a type i firm to be compliant then $j 1=c$ if it is optimal for a type $\mathrm{k}$ firm to default on taxes then $j 3=d$.
} 


\section{Proof of Proposition Two:}

Say $w_{2}>w_{1}$ where $w_{1}$ and $w_{2}$ are both wages offered by type $i$ and type $j$ firms

respectively in equilibrium and $p_{j} \geq p_{i}$. That is firm $j$ is either a firm of the same type as firm $i$ or one managed by a higher ability manager. We note that if $w_{1}$ is the wage paid by the lowest wage compliant firm across all firms:

$$
V_{i}^{c}\left(w_{1}\right)>V_{i}^{d}\left(w_{1}\right)
$$

Equation (22) just ensures that complying is more profitable for this firm. First we show that (22) implies a higher profit stream for the compliant firm paying $w_{1}$. We note that the lowest wage compliant firm must have productivity that is at least as low as any other compliant firm, since from Proposition One higher productivity firms pay weakly higher wages. From (2) equation (22) implies:

$$
\begin{aligned}
& \pi_{i}^{c}\left(w_{1}\right)-\pi_{i}^{d}\left(w_{1}\right)>\lambda \int_{\underline{w}}^{\bar{w}}\left\{\max \left[V_{i}^{d}\left(w_{1}\right), E(x)\right]-V_{i}^{d}\left(w_{1}\right)\right\} d F(x) \\
& -\lambda \int_{\underline{w}}^{\bar{w}}\left\{\max \left[V_{i}^{c}\left(w_{1}\right), E(x)\right]-V_{i}^{c}\left(w_{1}\right)\right\} d F(x)+\delta \max \left\{\left[\gamma V_{i}^{c}\left(w_{1}\right),\left[V_{i}^{c}\left(w_{1}\right)-U\right]\right\}\right. \\
& \left.-\delta \max \left\{\gamma V_{i}^{d}\left(w_{1}\right),\left[V_{i}^{d}\left(w_{1}\right)-U\right]\right\}\right]
\end{aligned}
$$

Since (22) holds it must be true that:

$$
\lambda \int_{\underline{w}}^{\bar{w}}\left\{\max \left[V_{i}^{d}\left(w_{1}\right), E(x)\right]-V_{i}^{d}\left(w_{1}\right)\right\} d F(x)-\lambda \int_{\underline{w}}^{\bar{w}}\left\{\max \left[V_{i}^{c}\left(w_{1}\right), E(x)\right]-V_{i}^{c}\left(w_{1}\right)\right\} d F(x)>0(24)
$$

This is so since (22) implies that there will be a range of values for $w$ where:

$E(x)]-V_{i}^{d}\left(w_{1}\right)>0$ but $\max \left[V_{i}^{c}\left(w_{1}\right), E(x)\right]-V_{i}^{c}\left(w_{1}\right)=0$ For wages less lower than in this range both terms are zero while for wages higher than in this range fro (22). Also from (22): 


$$
\delta \max \left\{\left[\gamma V_{i}^{c}\left(w_{1}\right),\left[V_{i}^{c}\left(w_{1}\right)-U\right]\right\}-\delta \max \left\{\gamma V_{i}^{d}\left(w_{1}\right),\left[V_{i}^{d}\left(w_{1}\right)-U\right]\right\}>0\right.
$$

Inequalities (24) and (25) imply from (23) that if (22) holds :

$$
\pi_{i}^{c}\left(w_{1}\right)-\pi_{i}^{d}\left(w_{1}\right)>0
$$

Next given that firm $i$ is compliant we explore the possibility that a firm of type $j$ (which has weakly higher productivity) and pays the higher wage $w_{2}$, could be at least as well off being non-compliant rather than defaulting. That is we explore the possibility that:

$$
V_{j}^{c}\left(w_{2}\right) \leq V_{j}^{d}\left(w_{2}\right)
$$

Then from (2)

$$
\begin{aligned}
& \pi_{j}^{d}\left(w_{2}\right)-\pi_{j}^{c}\left(w_{1}\right) \geq \lambda \int_{\underline{w}}^{\bar{w}}\left\{\max \left[V_{j}^{c}\left(w_{2}\right), E(x)\right]-V_{j}^{c}\left(w_{2}\right)\right\} d F(x) \\
& -\lambda \int_{\underline{w}}^{\bar{w}}\left\{\max \left[V_{j}^{d}\left(w_{2}\right), E(x)\right]-V_{j}^{d}\left(w_{2}\right)\right\} d F(x) \\
& +\delta \max \left\{\gamma V_{j}^{d}\left(w_{2}\right),\left[V_{j}^{d}\left(w_{2}\right)-U\right]\right\}-\delta \max \left\{\gamma V_{j}^{c}\left(w_{2}\right),\left[V_{j}^{c}\left(w_{2}\right)-U\right]\right\}
\end{aligned}
$$

If (27) holds the right hand side of (28) must be weakly positive and we can say that:

$$
\pi_{j}^{d}\left(w_{2}\right)-\pi_{j}^{c}\left(w_{2}\right) \geq 0
$$

Next we will show that given $w_{2}>w_{1}$, then if the elasticity of punishment with respect to the tax bill is greater than or equal to unity: (27) cannot hold, that is it must be that:

$$
V_{i}^{c}\left(w_{2}\right)>V_{i}^{d}\left(w_{2}\right)
$$

That is we show that if complying is optimal at the lowest wage complying firm, it must be optimal at any arbitrarily chosen higher wage firm. To see this we note that differentiating (1) we get: 


$$
\begin{aligned}
& \frac{\partial \pi(w)_{i}^{c}}{\partial w}-\frac{\partial \pi(w)_{i}^{d}}{\partial w}=\Omega(B) \frac{\partial \Theta[n(w)]}{\partial n(w)} \frac{\partial n(w)}{\partial w} \\
& +\left(t n(w)+w t \frac{\partial n(w)}{\partial w}\right)\left(\Theta[n(w)] \frac{\partial \Omega(B)}{\partial B}-1\right)
\end{aligned}
$$

Since $\frac{\partial \Theta[n(w)]}{\partial n(w)}>0$ and $\frac{\partial n(w)}{\partial w}>0$ by assumption a sufficient condition for (31) to be positive is: $\Theta[n(w)] \frac{\partial \Omega(B)}{\partial B}>1$. But from (1) we see that $\pi_{i}^{c}(w)-\pi_{i}^{d}(w)>0$ implies that:

$$
\frac{B}{\Omega(B)}<\Theta[n(w)]
$$

But since the elasticity of punishment with respect to the tax bill: $\frac{\partial \Omega(B)}{\partial B} \frac{B}{\Omega(B)}$ is greater than unity by assumption we can say that $\Theta[n(w)] \frac{\partial \Omega(B)}{\partial B}>\frac{\partial \Omega(B)}{\partial B} \frac{B}{\Omega(B)}>1$. We conclude that $\frac{\partial \pi\left(w_{1}\right)_{i}^{c}}{\partial w}-\frac{\partial \pi\left(w_{1}\right)_{i}^{d}}{\partial w}>0$ and the profitability of being compliant is increasing faster than the profitability of being non-compliant. This means (27) cannot hold. Finally we note that if firm type $j$ is a higher productivity type than firm type we can replace $i$ with $j$ in the derivative in equation (31) and the analysis above showing the derivative is positive still holds

\section{Proof of Proposition Three:}


The value of the lowest equilibrium wage offer is: $E(\underline{w)}$. Say this wage is offered by type $j$ firm in equilibrium where $j \geq i$ and where $i$ is the lowest ability type. If a type $i$ worker preferred self-employment to this offer then:

$$
V_{i}^{h}\left[p_{i}, w, n(w)\right]>E(\underline{w)} \text { where } \mathrm{h} \in(c, d)
$$

But since for any other worker type $k \neq i$ it must be that $p_{k}>p_{i}$ in which case it follows from the definition of profits and the value of the firm (1) and (2) that

$V_{k}^{h}\left[p_{k}, w, n(w)\right]>V_{i}^{h}\left[p_{k}, w, n(w)\right]>E(\underline{w)}$. That is it must be that if type $i$ workers would prefer self-employment to the lowest wage job, the same would be true for all workers. This means that no firm could offer such a contract and attract any workers and such an offer cannot be an equilibrium contract. It must be that in equilibrium the lowest wage contract is sufficiently attractive to attract at least the lowest ability worker or else it cannot attract any workers.

\section{Proof of Proposition Four:}

From Proposition One the highest ability managers (we can call these group z) will manage the largest, highest wage firm. Since any manager can choose to be an ownaccount firm at any point in time, the profit of being the highest wage manager must be at least as high as the profit of being an own-account worker in equilibrium:

$$
\pi_{z}^{j}(\bar{w})>p_{z} q\left(n_{0}\right)
$$

Where $j \in(c, d)$. Since this is the largest firm and since $q_{n}(n)>0$ and $q_{n n}(n)<0$ by

assumption and $n\left(\overline{w_{t}}\right)>n^{\circ}$ by assumption, the additional output generated by the last 
$n^{\circ}$ workers in the highest wage firm is less than the high ability manager could produce as an own-account worker:

$$
p_{z}\left\{q\left[n\left(\overline{w_{t}}\right)\right]-q\left[n\left(\overline{w_{t}}\right)-n^{o}\right]\right\}<p_{z} q\left[n^{o}\right]
$$

That is even if the highest wage firm paid a wage to the marginal worker equal to the value of their marginal product, from (35) this would be less than the workers earnings in self-employment (if the worker is from the highest ability group). In fact of course the firm will also incur either an additional tax liability if it is compliant or an increase in the likelihood of a penalty if it is defaulting. It follows that the highest wage firm could not pay a wage high enough to attract the highest ability worker away from selfemployment $\square$

\section{Appendix 2: Solving the equilibrium wage distribution}

Type 0 and type 1 workers

All type 0 self-employed workers will be own-account workers since they cannot profitably hire another worker. This is immediately clear from (15) and (16) where the value of marginal product of a type 1 worker in a type 0 firm is less than the value of a type 1 workers output in self-employment. Using a similar argument a type 2 worker could never be profitably employed in a type 1 firm so that type 1 employers can only profitably hire type 0 workers.

The lowest wage type 1 firm will have labour supply: $\frac{L_{0}}{M} \frac{\delta \lambda}{\{\delta+\lambda\}^{2}}$ from (14). We will assume that there are some non-compliant employers in equilibrium which implies 
from Proposition Two that the lowest wage type 1 employers are non-compliant. From (17) this amounts to:

$$
\frac{L_{0} \delta \lambda}{[\delta+\lambda]^{2}} s^{\frac{1}{\sigma-1}}<M
$$

This is Condition 1. To focus on an equilibrium where there are some compliant firms amounts to assuming that $F^{*}<1$ in equation (18). This is Condition 2. Combining (36) and (18) we see that if Condition 1 and Condition 2 both hold then $M$ lies in the range ${ }^{21}$ :

$$
\frac{\delta \lambda}{[\delta+\lambda]^{2}} L_{0} s^{\frac{1}{\sigma-1}}<M<\frac{\lambda}{\delta} L_{0} s^{\frac{1}{\sigma-1}}
$$

If some type 1 self-employed workers hire other workers the lowest wage they will offer is the reservation wage of type 0 workers $p_{0}$ :

$$
\underline{w}=p_{0}
$$

If the lowest wage firm were paying a wage $\tilde{w}_{1}>p_{0}$ from (14) they would have labour supply of.

$$
n(\underline{w})=\frac{L_{0}}{M} \frac{\delta \lambda}{[\delta+\lambda]^{2}}
$$

This firm can cut the wage to $p_{0}$ and have the same labour supply but higher profit. This is because the lowest wage firm attracts no workers from other firms and will lose workers to any firm that offers their workers a job. The only workers the lowest wage firm attracts are self-employed type 0 workers who have received no better offer. The lowest wage firm gains no advantage from offering these workers more than their reservation wage. Free entry ensures that all type 1 firms must make the same profit in

\footnotetext{
${ }^{21}$ It is straightforward to show that this range is positive if $\left[\frac{\delta}{\delta+\lambda}\right]^{2}<1$ which must be true.
} 
self-employment, that is if one firm is earning a higher profit than another the lower profit firm can imitate the higher profit firm so that their cannot be an equilibrium with differences in profit between the same firm type. The stream of profit for an ownaccount type 1 firm is: $p_{1}$. From (1) and (39) the condition that the profit of the lowest wage type 1 employer is equals that of an own-account worker in equilibrium is:

$$
\pi_{1}(\underline{w})=p_{1}=\left(p_{1}-p_{0}\right) \frac{L_{0}}{M} \frac{\delta \lambda}{[\delta+\lambda]^{2}}-s p_{0} t\left[\frac{L_{0}}{M} \frac{\delta \lambda}{[\delta+\lambda]^{2}}\right]^{\sigma}
$$

From equation (40) we can solve for the equilibrium value of $M$ the mass of employers. Next we would like to solve for the mass of type 1 workers who are employers in equilibrium. Given random matching, that no type 0 workers make offers and the fact that all offers by type 1 employers must be less than those by type 2 employers from Proposition One, the percentage of offers made by type 1 employers is the mass of type 1 employers divided by the total mass of employers and this is the value of the wage offer distribution for the highest wage type 1 employer:

$$
F\left(\bar{w}_{1}\right)=\frac{m_{1}}{M}
$$

The mass of firms equals the mass of type 1 and type 2 employers. We will assume that all type 2 self-employed workers employ others (we know that type 2 workers are all selfemployed from Proposition Four but we will assume we are in an equilibrium where it is more profitable to be an employer rather than an own-account type 2 worker). This assumption is enforced by parameter restrictions which we call Condition 3 and these restrictions are discussed later. If type 2 workers are employers then:

$$
M=m_{1}+m_{2}=m_{1}+L_{2}
$$


From (41) and (42) $)^{22}$ :

$$
F\left(\bar{w}_{1}\right)=\frac{M-L_{2}}{M}
$$

We will assume an equilibrium that some type 1 employers are non-compliant and some higher wage type 1 employers are compliant. This is Condition 4 and amounts to the assumption that $0<F^{*}<F\left(\bar{w}_{1}\right)$ which from (18) and (43) implies:

$$
0<\frac{\delta+\lambda}{\lambda}-\sqrt{\frac{\lambda}{\delta} \frac{L_{0}}{M} s^{\frac{1}{\sigma-1}}}<\frac{M-L_{2}}{M}
$$

The profit of all type 1 employers and own-account workers must be equal in equilibrium implying for compliant and non-compliant type 1 employers respectively:

Compliant firms: $\pi_{1}(\underline{w})=\pi(w)=p_{1}=\left[p_{1}-w(1+t)\right] \frac{L_{0}}{M} \frac{\delta \lambda}{\{\delta+\lambda[1-F(w)]\}^{2}}$

Non-ompliant firms: $\pi(w)=p_{1}=\left(p_{1}-w\right) \frac{L_{0}}{M} \frac{\delta \lambda}{\{\delta+\lambda[1-F(w)]\}^{2}}-\operatorname{swt}\left\{\frac{L_{0}}{M} \frac{\delta \lambda}{\{\delta+\lambda[1-F(w)]\}^{2}}\right\}^{\sigma}$

From (41) and using the value of $M$ that solves (40) we can solve for the wage in terms of the wage offer distribution over the range of offers made by type 1 firms: $\left(p_{0}, \bar{w}_{1}\right)^{23}$ :

\footnotetext{
${ }^{22}$ We note here that we must choose parameter values such that $L_{2}<M$ to ensure that this is positive. We also note that we must ensure that the fraction of type two workers who are self employed is greater than the number of type 1 employers from (41) and (7): $u_{1}=\frac{\delta M}{\delta M+\lambda L_{2}}>m_{1}=\frac{M-L_{2}}{L_{1}}$ ${ }^{23}$ It is easier to solve for the inverse wage offer distribution and we do this for simplicity.
} 


$$
\begin{aligned}
& \text { Compliant firms: } w=\frac{p_{1}}{1+t}\left\{1-[\delta+\lambda[1-F(w)]]^{2} \frac{M}{L_{0} \delta \lambda}\right\} \\
& \text { Non-compliant firms: } w=\frac{p_{1}\left\{\frac{L_{0}}{M} \frac{\delta \lambda}{\{\delta+\lambda[1-F(w)]\}^{2}}-1\right\}}{\frac{\delta \lambda}{M} \frac{\delta \lambda}{\{\delta+\lambda[1-F(w)]\}^{2}}+\operatorname{st}\left\{\frac{L_{0}}{M} \frac{\delta \lambda}{\{\delta+\lambda[1-F(w)]\}^{2}}\right\}^{\sigma}}
\end{aligned}
$$

From (45) and (43) we note that the highest wage offered by a type 1 employer is:

$$
\bar{w}_{1}=\frac{p_{1}}{1+t}\left\{1-\left[\delta+\lambda \frac{L_{2}}{M}\right]^{2} \frac{M}{L_{0} \delta \lambda}\right\}
$$

Type 2 workers

It follows from Proposition Four that type 2 workers (the highest ability group will all be self-employed. As discussed above firms only hire workers with less ability than their manager, so type 2 employers could hire type 0 or type 1 workers in equilibrium. We will impose parameter values such that all type 2 employers offer a wage high enough to attract both type 0 and type 1 workers in equilibrium. This is called: Condition 5 . We will discuss what this restriction implies below. The lowest wage that a type 2 employer will offer in an equilibrium where all type 2 employers offer wages that attract type 1 workers is:

$$
\underline{w}_{2}=p_{1}
$$

It can never make sense for the lowest wage type 2 employer to offer more than the reservation wage of type 1 workers, which is the profit a type 1 worker can earn in selfemployment as given by (40) above. If the lowest wage type 2 firm were paying a wage $\widetilde{w}_{2}>p_{1}$ from (14) they would have labour supply of:

$$
n\left(p_{1}\right)=\frac{L_{1}+L_{0}}{M} \frac{\delta \lambda}{\left\{\delta+\lambda\left[1-F\left(p_{1}\right)\right]\right\}^{2}}
$$


Since if they are the lowest wage type 2 employer that attracts type 1 workers, the wage must be no higher than the reservation wage of type 1 workers since the lowest wage firm will not attract any additional workers by offering more than this. The profit of the lowest wage type 2 firm that hires both worker types is in turn:

$$
\pi_{2}\left(p_{1}\right)=\left[p_{2}-p_{1}(1+t)\right] \frac{\left(L_{1}+L_{0}\right)}{M} \frac{\delta \lambda}{\left\{\delta+\lambda\left[1-F\left(p_{1}\right)\right]\right\}^{2}}
$$

Since there can be no mass points on the wage offer distribution we can set $F\left(p_{1}\right)=F\left(\bar{w}_{1}\right)^{24}$. In equilibrium we will see that the wage offer distribution will be continuous over the range $\left(p_{0}, \bar{w}_{1}\right)$ for offers by type 1 employers. There will be a discontinuity at $\bar{w}_{1}$ to the lowest wage a type 2 employer offers which is $p_{1}$. We know that $p_{1}$ must be greater than $\bar{w}_{1}$ since no type 1 employer could profitably pay a wage of $p_{1}$. The higher part of the wage offer distribution comprising offers by type 2 employers will be continuous over the range: $\left(p_{1}, \bar{w}_{2}\right)$.

To establish that type 2 employers will not deviate to hiring only type 0 workers (Condition 3 holds) we must show that when a type 2 firm chooses any wage between the lowest $\left(p_{0}\right)$ and highest $\left(\bar{w}_{1}\right)$ wage offered by type 1 firms that they would make less profit than they would in (50) which is the profit of a type 2 employer hiring both worker types. To check this we insert type 2 productivity and the highest type 1 wage given in (47) into (46) the profit of a type 1 employer:

\footnotetext{
${ }^{24}$ As in BM there can be no mass points on the equilibrium wage offer distribution since if there were a firm offering a wage slightly above the wage where there is a mass point will get higher profit than firms at the mass point which cannot be an equilibrium.
} 


$$
\begin{aligned}
& {\left[p_{2}-p_{1}(1+t)\right] \frac{\left(L_{1}+L_{0}\right)}{M} \frac{\delta \lambda}{\left\{\delta+\lambda\left[\frac{L_{2}}{M}\right]\right\}^{2}}>p_{1}+\left[p_{2}-p_{1}\right] \frac{L_{0}}{M} \frac{\delta \lambda}{\left\{\delta+\lambda\left[\frac{L_{2}}{M}\right]\right\}^{2}}} \\
& \text { Or } \quad\left[p_{2}-p_{1}(1+t)\right] \frac{\left(L_{1}+L_{0}\right)}{p_{1} L_{1}+p_{2} L_{0}}>1
\end{aligned}
$$

The highest wage type 2 employer offers the highest wage $F\left(\bar{w}_{2}\right)=1$ and from (14)

labour supply for this firm is: $n\left(\bar{w}_{2}\right)=\left(\frac{L_{1}+L_{0}}{M}\right) \frac{\lambda}{\delta}$ and profits are:

$$
\pi_{2}(\bar{w})=\pi_{2}\left(p_{1}\right)=\left[p_{2}-\bar{w}(1+t)\right] \frac{\left(L_{1}+L_{0}\right)}{M} \frac{\lambda}{\delta}
$$

Since all type 2 employers must make equal profit we can solve for the highest wage from (52) given that we have solved for $M$ in equation (40) and type 2 profit in (50):

$$
\bar{w}=\frac{p_{2}}{1+t}-\frac{\pi\left(p_{1}\right) M \delta}{(1+t)\left(L_{1}+L_{0}\right) \lambda}
$$

The wage offer distribution for type 2 employers who offer wages between $p_{1}$ and $\bar{w}$ can be solved by equating profit of type 2 firms in this range with $\pi\left(p_{1}\right)$ :

$$
\pi_{2}(w)=\pi\left(p_{1}\right)=\left[p_{2}-w(1+t)\right] \frac{L_{1}+L_{0}}{M} \frac{\delta \lambda}{\{\delta+\lambda[1-F(w)]\}^{2}}
$$

From this the inverse wage offer distribution is:

$$
w=\frac{p_{2}}{1+t}-\frac{\pi\left(p_{1}\right) M\{\delta+\lambda[1-F(w)]\}^{2}}{(1+t)\left(L_{1}+L_{0}\right) \delta \lambda}
$$

To illustrate the model we proceed by assuming parameter values and solving a numerical value. We assume that $\beta=1$ so that $\sigma=2$. That is we assume a linear relationship between firm size and the arrival rate of tax inspectors. This ensures that the solution for $M$ in (40) is a quadratic equation: 


$$
-\left(p_{1}-p_{0}\right) L_{0} \frac{\delta \lambda}{[\delta+\lambda]^{2}} M+p_{1} M^{2}+s p_{0} t\left[L_{0} \frac{\delta \lambda}{[\delta+\lambda]^{2}}\right]^{2}=A M+B M^{2}+C=0
$$

